\title{
Pengaruh Motivasi Belajar Guru Terhadap Keterampilan Membuat Bahan Ajar Berbasis Informasi Dan Teknologi Di SMP Negeri 139 Jakarta
}

\author{
Khoirul Umam ${ }^{1}$, Tjipto Djuhartono², Puput Irfansyah ${ }^{3}$ \\ Universitas Indraprasta PGRI, Jakarta ${ }^{1,2,3}$
}

\begin{abstract}
The purpose of this research activity is to measure and determine whether or not there is influence between motivation to study MS Power Point and Blog programs on teacher skills in making presentation slides and Blogs by using MS Power Point and Blog programs in information-based teacher teaching materials preparation training programs and technology at 139 Jakarta Public Middle School. The target to be achieved specifically in this research activity is the output of research carried out can be used as an indicator of decisions and policies for the Head of Jakarta SMP Negeri 139 in an effort to improve the competence of teachers in the schools they lead. The type of research carried out is quantitative descriptive using a statistical approach from the primary data obtained. The method used in the research activities at 139 Jakarta Public Middle School is through a survey using a questionnaire and literature review as a support in this study. The results showed that there was a very low influence between teacher learning motivation and the teacher's ability to make teaching materials as evidenced by the calculation of the correlation coefficient of 0.043 or $4.3 \%$ which could be interpreted as teachers' awareness to learn and master teaching skills using learning media Information and Technology based is very low.
\end{abstract}

Keywords: Motivation to learn, skills to make teaching materials

\section{Pendahuluan}

Dampak dari perkembangan informasi dan teknologi saat ini adalah menuntut setiap individu untuk selalu siap dan tanggap dalam menerima dan menghadapi dinamika informasi dan teknologi itu sendiri. Kondisi ini merupakan sebuah realitas yang tidak bisa dipungkiri dan dihindari, termasuk dalam dunia pendidikan. Guru, secara lebih spesifik, adalah salah satu pelaku pendidikan yang terlibat langsung dalam proses pendidikan dan memiliki peran penting dan strategis dalam mencetak output dari peserta didik yang berkualitas, lebih spesifik lagi adalah mencetak siswa yang mampu beradaptasi dengan dinamika teknologi dan informasi di masa depan. Untunk itu, guru pada akhirnya juga dituntut untuk mampu menguasai keterampilan 
dalam mengoperasikan berbagai media pembelajaran yang berbasis teknologi informasi.

Dalam Undang-Undang Republik Indonesia No. 14 tahun 2005 di Bab 1 Pasal 1 Butir 1, tentang Guru dan Dosen, menyatakan bahwa "guru adalah pendidik profesional dengan tugas utama mendidik, mengajar, membimbing, mengarahkan, melatih, menilai dan mengevaluasi peserta didik pada pendidikan anak usia dini jalur pendidikan formal, pendidikan dasar, dan pendidikan menengah." Lebih lanjut dinyatakan pada Bab 1 Pasal 1 butir 4 bahwa "profesional adalah pekerjaan atau kegiatan yang dilakukan seseorang dan menjadi sumber penghasilan kehidupan yang memerlukan keahlian, kemahiran, atau kecakapan yang memenuhi standar mutu atau norma tertentu serta memerlukan pendidikan profesi." Dari menelaah butir-butir dari UU-RI No. 14 tahun 2005 di atas, dapat diterjemahkan bahwa seorang guru adalah tenaga pendidik profesional yang dalam profesinya wajib memenuhi standar kualifikasi yang sudah ditetapkan oleh pemerintah. Dengan kata lain, dalam menjalankan profesinya, guru dituntut untuk dapat meningkatkan kompetensi sesuai profesi yang dijalankannya. Sehingga berangkat dari hal tersebut, maka terkait dengan upaya meningkatkan komptensi guru tersebut, Peraturan Pemerintah Republik Indonesia No. 74 Tahun 2008 Tentang Guru pada Bab II tentang Kompetensi dan Sertifikasi di Pasal 2 menyatakan bahwa "Guru wajib memiliki Kualifikasi Akademik, kompetensi, Sertifikat Pendidik, ..." lebih lanjut dinyatakan pada Bab II di Bagian Kesatu tentang Kompetensi di Pasal 3 butir (4) poin f, bahwa salah satu kompetensi yang wajib dimiliki oleh guru adalah pemanfaatan teknologi pembelajaran. Dengan kata lain, PP-RI no 74 tahun 2008 Tentang Guru tersebut dapat diterjemahkan bahwa guru, dalam menjalankan profesinya sebagai tenaga pendidik, wajib memiliki dan meningkatkan kompetensi di bidang informasi dan teknologi sebagai sarana pembelajaran yang dapat mendukung kelancaran dan kualitas pembelajaran di kelas.

Dari menelaah dua ketentuan di atas, jelas sekali bahwa adalah merupakan sebuah keharusan bagi guru sebagai individu profesional dalam bidang pendidikan wajib untuk selalu meningkatkan kemampuan dan keterampilannya dalam memanfaatkan berbagai sarana dan prasarana pembelajaran, yang salah satunya 
adalah memanfaatkan teknologi dan informasi dalam rangka upaya meningkatkan mutu pendidikan dari peserta didik.

Penelitian ini berencana untuk meneliti dan mencermati persoalan yang terjadi pada SMP Negeri 139 Jakarta sehubungan dengan peningkatan salah satu aspek kompetensi guru mata pelajaran, yaitu keterampilan dan penguasaan media pembelajaran berbasis teknologi informasi. Salah satu persoalan yang dihadapi oleh SMP Negeri 139 Jakarta adalah keterbatasan kompetensi dari sebagian guru mata pelajaran dalam memanfaatkan penggunaan komputer dan multimedia dalam upaya meningkatkan kualitas sumber daya manusia dari guru-guru yang mengajar mata pelajaran di kelas. Beberapa guru mengalami kendala dalam mengembangkan metode pengajarannya melalui penggunaan multi media, khususnya komputer. Padahal di sisi lain, penggunaan multi media saat ini merupakan sebuah keharusan dalam pengembangan metode pembelajaran di kelas.

Keterbatasan yang dihadapi oleh guru mata pelajaran di SMP Negeri 139 Jakarta dalam memberikan materi pelajaran melalui multi media antara lain adalah belum familiar dalam media pembelajaran berbasis informasi dan teknologi, misalnya dalam mengoperasikan program Microsoft Office Power Point dan Blog, beberapa guru bahkan masih belum bisa mengoperasikan komputer secara umum mulai dari menghidupkan hingga shut down komputer, tidak tahu bagaimana mengoperasikan program internet seperti mengunduh foto atau file di sebuah website ke dalam MS. Power Point, tidak menguasai cara dalam membuat slide untuk bahan mengajar dengan menggunakan MS. Power Point. Kondisi ini terjadi dikarenakan sebagian besar guru di SMP Negeri 139 Jakarta merupakan guru senior yang selama ini terbiasa menggunakan cara klasikal dalam penggunaan alat belajar di kelas, yaitu menulis di papan tulis atau menggunakan buku teks.

Faktor lain dalam persoalan yang dihadapi oleh guru adalah masih rendahnya kesadaran guru mata pelajaran yang bersangkutan terhadap pentingnya penggunaan alat mengajar berbasis teknologi informasi dan multimedia dalam rangka meningkatkan kompetensi guru dan kualitas pengajaran terhadap siswa di kelas. Kondisi ini ditemui pada guru-guru yang sudah senior. Mereka beranggapan dalam metode pembelajaran di kelas tidak terlalu penting menggunakan komputer dan 
software, karena telah terbiasa dengan cara klasik dalam mengajar. Berdasarkan uraian dari latar belakang di atas, maka rumusan masalah yang akan diteliti adalah sebagai berikut: 1 . Apakah ada pengaruh antara pengaruh motivasi belajar terhadap keterampilan guru dalam membuat slide presentasi dan Blog dengan menggunakan program MS. Power Point dan Blog dalam program pelatihan persiapan bahan ajar guru berbasis informasi dan teknologi di SMP NEGERI 139 Jakarta?; 2.Seberapa besar pengaruh motivasi tersebut sehingga dapat memberikan dampak terhadap kemampuan guru dalam membuat slide presentasi melalui MS Power Point dan Blog ?; 3. Apa solusi yang dapat dimunculkan dari penelitian ini dalam rangka meningkatkan keterampilan guru dalam mengajar dengan menggunakan teknologi pembelajaran berbasis teknologi informasi?

\section{Tinjauan Pustaka}

Motivasi merupakan kekuatan internal yang tak dapat dibandingkan dengan orang lain secara langsung. Bartol (1998: p. 382) mendefinisikan Motivasi sebagai The forces that energizes behavior, gives direction to behavior, and underlies the tendency to persist. Berdasarkan definisi tersebut, jelas bahwa dalam rangka mencapai sebuah tujuan, seseorang harus memiliki rangsangan dan energi (semangat) yang cukup, harus memiliki fokus yang jelas terhadap apa yang ingin dicapainya, dan harus selalu mau memunculkan energi dan semangatnya untuk mencapai tujuan tersebut dalam jangka panjang.

Benowitz (2001: p.127) mendefinisikan motivasi adalah, "the force that causes an individual to behave in a specific way". Berdasarkan dari definisi di atas, maka dapat diterjemahkan bahwa motivasi merupakan sebuah kekuatan internal dari individu yang membuat seseorang berperilaku kepada tujuan tertentu secara spesifik. Herzberg dalam Benowitz (2001: p. 130) menjelaskan tentang motivasi dari penelitian yang telah dilakukan melalui wawancara terhadap lebih dari dua ratus insinyur dan akuntan. Atas dasar penelitiannya, Herzberg menemukan dua kelompok faktor-faktor besar yang mempengaruhi kerja seseorang dalam organisasi. Faktor-faktor penyebab kepuasan kerja (job satisfaction) mempunyai pengaruh pendorong bagi prestasi dan semangat kerja, dan faktor-faktor penyebab ketidakpuasan kerja (job dissatisfaction) memiliki pengaruh negatif. Atas dasar 
penemuan dari penelitian Herzberg tersebut, beliau membedakan antara yang diebut dengan motivators atau pemuas (satisfiers) dan faktor-faktor pemeliharaan (hygienic factors) atau dissatisfiers. Motivators memiliki pengaruh untuk meningkatkan prestasi kerja. Hygienic factors mencegah merosotnya semangat kerja atau efisiensi, dan meskipun faktor-faktor ini tidak dapat memotivasi, namun dapa menimbulkan ketidakpuasan kerja atau menurunkan produktifitas. Perbaikan terhadap Hygienic Factors akan dapat mengurangi atau menghilangkan ketidakpuasan kerja tetapi tidak dapat digunakan sebagai sumber kepuasan kerja.

Mathis (2010: p.157) mendefiniskan motivasi sebagai the desire within a person causing the person to act. Definisi Mathis menjelaskan bahwa motivasi dipandang sebagai hasrat dari individu yang menyebabkan seseorang melakukan suatu tindakan. Lebih lanjut Mathis menjelaskan bahwa orang biasanya bertindak untuk mencapai tujuan, hal ini berarti bahwa motivasi adalah sebuah perjalanan yang diarahkan pada tujuan tertentu.

Menurut T. Hani Handoko (2012: hal. 251), motivasi merupakan kegiatan yang mengakibatkan, menyalurkan dan memelihara perilaku manusia. Lebih lanjut Hani Handoko mengatakan bahwa motivasi bukanlah satu-satunya faktor yang mempengaruhi tingkat prestasi seseorang. Dua faktor lain yang terlibat adalah kemampuan individu dan pemahan tentang perilaku yang diperlakukan untuk mencapai prestasi yang tinggi atau disebut persepsi peranan.

McClelland dalam Hani Handoko (2012: hal. 261) mengemukakan bahwa ada korelasi positif antara kebutuhan berprestasi dengan prestasi dan sukses pelaksanaan. Menurut McLelland, kebutuhan prestasi dapat dikembangkan pada orang dewasa. Orang-orang yang berorientasi prestasi memiliki karakteristik yang dapat dikembangkan, yaitu:

1. Menyukai pengambilan keputusan yang layak (moderat), sebagai fungsi keterampilan, bukan kesempatan; menyukai suatu tantangan, dan menginginkan tanggung jawab pribadi bagi hasil-hasil yang dicapai

2. Memiliki kecenderungan untuk menetapkan tujuan-tujuan prestasi yang layak dan menghadapi resiko yang sudah diperhitungkan

3. Memiliki kebutuhan yang kuat akan umpan balik tentang apa yang telah dikerjakannya 
4. Memiliki keterampilan dalam perencanaan jangka panjang dan memiliki kemampuan-kemampuan organisasi.

\section{Pengertian Keterampilan (Skills)}

Istilah keterampilan sulit untuk didefinisikan dengan suatu kepastian yang tidak dapat dibantah. Keterampilan dapat menunjuk pada aksi khusus yang ditampilkan atau pada sifat di mana keterampilan itu dilaksanakan. Banyak kegiatan dianggap sebagai suatu keterampilan, atau terdiri dari beberapa keterampilan dan derajat penguasaan yang dicapai oleh seseorang menggambarkan tingkat keterampilannya. Hal ini bisa terjadi karena kebiasaan yang sudah diterima umum untuk menyatakan bahwa satu atau beberapa pola gerak atau perilaku yang diperhalus bisa disebut keterampilan, misalnya menulis, memainkan gitar atau piano, menyetel mesin, berjalan, berlari, melompat, dsb. Jika ini yang digunakan, maka kata 'keterampilan' yang dimaksud adalah sebagai kata benda. Di pihak lain, keterampilan juga bisa digunakan sebagai kata sifat, walaupun kalau hal ini digunakan, kata tersebut sudah berubah strukturnya hanya menjadi terampil. Kata ini digunakan untuk menunjukkan suatu tingkat keberhasilan dalam melakukan suatu tugas.

Schmidt (1991) mencoba menggambarkan definisi keterampilan tersebut dengan meminjam definisi yang diciptakan oleh E.R. Guthrie, yang mengatakan bahwa: "Keterampilan merupakan kemampuan untuk membuat hasil akhir dengan kepastian yang maksimum dan pengeluaran energi dan waktu yang minimum." Sedangkan Singer (1980) menyatakan bahwa "keterampilan adalah derajat keberhasilan yang konsisten dalam mencapai suatu tujuan dengan efisien dan efektif."

Berdasarkan kedua definisi di atas, walaupun dinyatakan secara berbeda namun sama-sama memiliki unsur-unsur pokok yang menjadi ciri dari batasan keterampilan. Unsur-unsur itu adalah:

1. Di dalam keterampilan terdapat beberapa tujuan yang berhubungan dengan lingkungan yang diinginkan.

2. Di dalam keterampilan pun terkandung keharusan bahwa pelaksanaan tugas atau pemenuhan tujuan akhir tersebut dilaksanakan dengan kepastian yang 
maksimum, terlepas dari unsur kebetulan atau untung-untungan. Jika seseorang harus melakukan suatu keterampilan secara berulang-ulang, maka hasil dari setiap ulangan itu relatif harus tetap, meskipun di bawah kondisi yang bervariasi maupun yang tidak terduga (Singer, 1980).

3. Keterampilan menunjuk pada upaya yang ekonomis, di mana energy yang dikeluarkan untuk melaksanakan suatu tugas tertentu harus seminimal mungkin, tetapi dengan hasil yang maksimal.

4. Keterampilan mengandung arti pelaksanaan yang cepat, dalam arti penyelesaian tugas gerak itu dalam waktu yang minimum. Semakin cepat pelaksanaan suatu gerak, tanpa mengorbankan hasil akhir (kualitas) yang diharapkan, maka akan membuat terakuinya keterampilan orang yang bersangkutan. Dalam hal ini perlu dimengerti bahwa mempercepat gerakan suatu tugas akan menimbulkan pengeluaran energi yang semakin besar, di samping membuat gerakan semakin sulit untuk dikontrol ketepatannya. Namun meskipun demikian, lewat latihan dan pengalaman semua unsur yang terlibat dalam menghasilkan gerakan yang terampil perlu dikombinasikan secara serasi

Sebagai perbandingan dari keempat unsur diatas, H.W. Johnson (dalam Singer, 1980) mengidentifikasi adanya empat aspek atau variabel yang mencirikan keterampilan. Keempat aspek itu adalah kecepatan, akurasi, bentuk, dan kesesuaian. Artinya, pertama keterampilan harus ditampilkan dalam batasan waktu tertentu, yang menunjukkan bahwa semakin cepat semakin baik. Kedua keterampilan harus menunjukkan akurasi yang tinggi sesuai dengan yang ditargetkan. Ketiga keterampilan pun harus dilaksanakan dengan kebutuhan energi yang minimal; (form atau bentuk menunjuk pada usaha yang ekonomis). Dan terakhir, keterampilan pun harus juga adaptif, yaitu tetap cakap meskipun di bawah kondisi yang berbeda-beda.

Berdasarkan kamus dari www.businessdictionary.com, skills (keterampilan) didefinisikan sebagai, "an ability and capacity acquired through deliberate, systematic, and sustained effort to smoothly and adaptively carryout complex activities or job functions involving ideas (cognitive skills), things (technical skills), 
and/or people (interpersonal skills)".

Menurut Bernowitz, keterampilan adalah kemampuan untuk menerjemahkan pengetahuan ke dalam tindakan yang menghasilkan kinerja yang diinginkan, diminta untuk membantu karyawan lain menjadi lebih produktif. Bernowitz memberikan kategori dari keterampilan sebagai berikut:

1). Technical, keterampilan teknikal menuntut keahlian khusus untuk menjalankan tugas-tugas tertentu

2). Human, keterampilan humanis ini menjelaskan kepada kita untuk bagaimana individu harus memiliki kemampuan berinteraksi dan bekerja dengan sesama rekan dalam organisasi

3). Conseptual, yaitu kemampuan yang harus dimiliki untuk menganalisis dan mmeecahkan setiap masalah serta mengenali dampak yang ditimbulkan dari masing-masing masalah tersebut.

\section{Metode Penelitian}

Tujuan dari penelitian yang dilakukan di SMP Negeri 139 Jakarta adalah sebagai berikut:

1). Mengetahui sejauh mana peran motivasi dapat mempengaruhi kemampuan guru untuk terampil mengoperasikan komputer dan menjalankan programprogram berbasis teknologi informasi terutama program MS Office Power Point 2007 dan Blog.

2). Mengukur besar hubungan dan pengaruh antara motivasi untuk menguasai program berbasis informasi dan tekonologi dan pengoperasian komputer yang terwujud dalam bentuk pelatihan terhadap keterampilan yang diperoleh dari pelatihan tersebut

\section{Desain Penelitian}

Penelitian ini menggunakan pendekatan kuantitatif yang bersifat pengaruh tunggal, yaitu untuk mengetahui adanya pengaruh dari satu variabel independen terhadap satu variable dependen. Subjek sekaligus populasi penelitian sejumlah 64 orang dalam penelitian ini adalah guru mata pelajaran di SMP Negeri 139 Jakarta yang beralamat di Jl. Bunga Rampai No.1, Duren Sawit, 13460, Jakarta Timur pada 
bulan Maret hingga Juli 2016. Data dalam penelitian ini dikumpulkan dengan menggunakan metode survey dan dokumentasi. Pengumpulan data dilakukan dengan menggunakan kuesioner dimana yang digunakan dalam penelitian ini adalah kuesioner motivasi belajar guru dan kuesioner tentang keterampilan guru dalam membuatkan slide presentasi di kelas.

\section{Hasil Dan Pembahasan}

\section{Gambaran Umum Responden}

Pada penelitian ini penulis akan mencari tahu apakah ada pengaruh motivasi belajar terhadap keterampilan membuat bahan ajar yang dilakukan oleh guru-guru peserta pelatihan tersebut di SMP Negeri 139 Jakarta. Data-data yang diperlukan dalam penelitian ini diperoleh melalui instrument kuesioner dengan pilihan jawab dengan menggunakan skala likert yang diajukan pada 64 responden.

Berdasarkan kuesioner tersebut dapat diidentifikasi karakteristik guru peserta pelatihan berdasarkan tiga karakteristik yaitu jenis kelamin, tingkat pendidikan dan usia sebagai mana yang tercantum pada tabel berikut:

Tabel 5.1 Karakteristik berdasarkan Jenis Kelamin

\begin{tabular}{|c|c|c|c|}
\hline No & Jenis Kelamin & Jumlah & Prosentase (\%) \\
\hline 1 & Laki-laki & 27 & $42,19 \%$ \\
\hline 2 & Perempuan & 37 & $57,81 \%$ \\
\hline & Total & 64 & $100 \%$ \\
\hline
\end{tabular}

Sumber : Data Diolah oleh peneliti (2015)

Dari hasil penelitian, jumlah responden berjenis kelamin perempuan sebesar 37 orang $(57,81 \%)$ dan sisanya responden berjenis kelamin laki-laki sebesar 27 orang $(42,19 \%)$. Sehingga dapat disimpulkan bahwa dari total jumlah peserta pelatihan yang mengikuti program pelatihan komputer berbasis Informasi dan Teknologi di SMP Negeri 139 Jakarta berjenis kelamin perempuan lebih banyak dari pada peserta berjenis kelamin laki-laki.

Tabel 5.2 Karakteristik Berdasarkan Tingkat Pendidikan Terakhir

\begin{tabular}{|c|c|c|c|}
\hline No & Tingkat Pendidikan & Jumlah & Prosentase (\%) \\
\hline 1 & S1 & 42 & 65.63 \\
\hline 2 & S2 & 8 & 12.50 \\
\hline 3 & S3 & 1 & 1.56 \\
\hline 4 & Non S1 & 13 & 20.31 \\
\hline
\end{tabular}




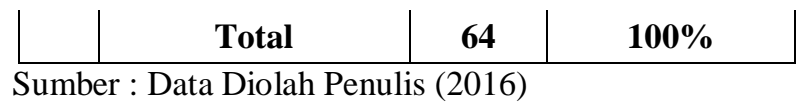

Dari data di atas dapat diketahui bahwa guru peserta pelatihan yang memiliki tingkat pendidikan akhir S1 sebanyak 42 orang $(65,63 \%)$, guru peserta pelatihan memiliki tingkat pendidikan akhir S2 sebanyak 8 orang $(12,50 \%)$, dan guru peserta pelatihan yang memiliki tingkat pendidikan S3 (Doktoral) sebanyak 1 orang $(1,56 \%)$ serta guru peserta pelatihan yang bergelar non Sarjana (S1) sebanyak 13 orang $(20,31 \%)$. Sehingga dapat disimpulkan bahwa dari total populasi peserta pelatihan, sebagian besar guru peserta pelatihan di SMP Negeri 139 Jakarta berpendidikan S1 (Sarjana).

\section{Tabel 5.3 Karakteristik berdasarkan Usia}

\begin{tabular}{|c|c|c|c|}
\hline No & Usia (Tahun) & Jumlah & Prosentase (\%) \\
\hline 1 & $30-40$ & 42 & $65,6 \%$ \\
\hline 2 & $50-70$ & 22 & $34,4 \%$ \\
\hline & Total & 64 & $100 \%$ \\
\hline
\end{tabular}

Sumber : Data Diolah Penulis (2016)

Dari data di atas dapat diketahui bahwa Guru di SMP Negeri 139 Jakarta yang memiliki usia kisaran 30-40 tahun sebanyak 42 orang $(65,6 \%)$, sedangkan Guru yang memiliki usia kisaran 50-70 tahun sebanyak 22 orang (34,4\%). Sehingga dapat disimpulkan sebagian besar guru di SMP Negeri 139 Jakarta berusia antara 30-40 tahun.

\section{Pengolahan Data Hasil Penelitian}

\section{Uji Validitas}

Dalam melakukan uji validitas, peneliti menyebarkan kuesioner kepada responden sebanyak 60 orang. Untuk mengukur uji validitas ini menggunakan rumus korelasi product moment dengan table kritis $\mathrm{r}_{\text {table }}$ Pearson's Product Moment diketahui 0,15979 untuk $\mathrm{n}=60$ dengan $\alpha=0,2$

a. Variabel Motivasi Belajar (X)

Tabel 5.4 Hasil Perhitungan r pada Variabel Motivasi Belajar (X)

\begin{tabular}{|c|c|c|c|c|c|c|c|c|c|c|c|c|c|c|c|c|c|c|c|c|c|c|}
\hline \multicolumn{23}{|c|}{ Correlations } \\
\hline & & Q1 & Q2 & Q3 & Q4 & Q5 & Q6 & Q7 & Q8 & Q9 & Q10 & Q11 & Q12 & Q13 & Q14 & Q15 & Q16 & \begin{tabular}{|l|} 
Q17 \\
\end{tabular} & Q18 & Q19 & Q20 & SKOR \\
\hline & $\begin{array}{l}\text { Pearson } \\
\text { Correlation }\end{array}$ & & .334 & $.320^{\prime}$ & .154 & .298 & .066 & .099 & .240 & -.007 & .007 & -.081 & -.217 & -.124 & .056 & -.112 & -.230 & D -.077 & -.038 & .060 & .095 & .191 \\
\hline Q1 & $\begin{array}{l}\text { Sig. (2- } \\
\text { tailed) }\end{array}$ & & .007 & .010 & .228 & .018 & .602 & .439 & .056 & .955 & .955 & .523 & .084 & .330 & .660 & .379 & .068 & .544 & 4. .765 & .639 & .457 & .131 \\
\hline & $\mathrm{N}$ & & 64 & 64 & 63 & 63 & 64 & 64 & 64 & & & & & & & & & 64 & 64 & 64 & & 84 \\
\hline
\end{tabular}




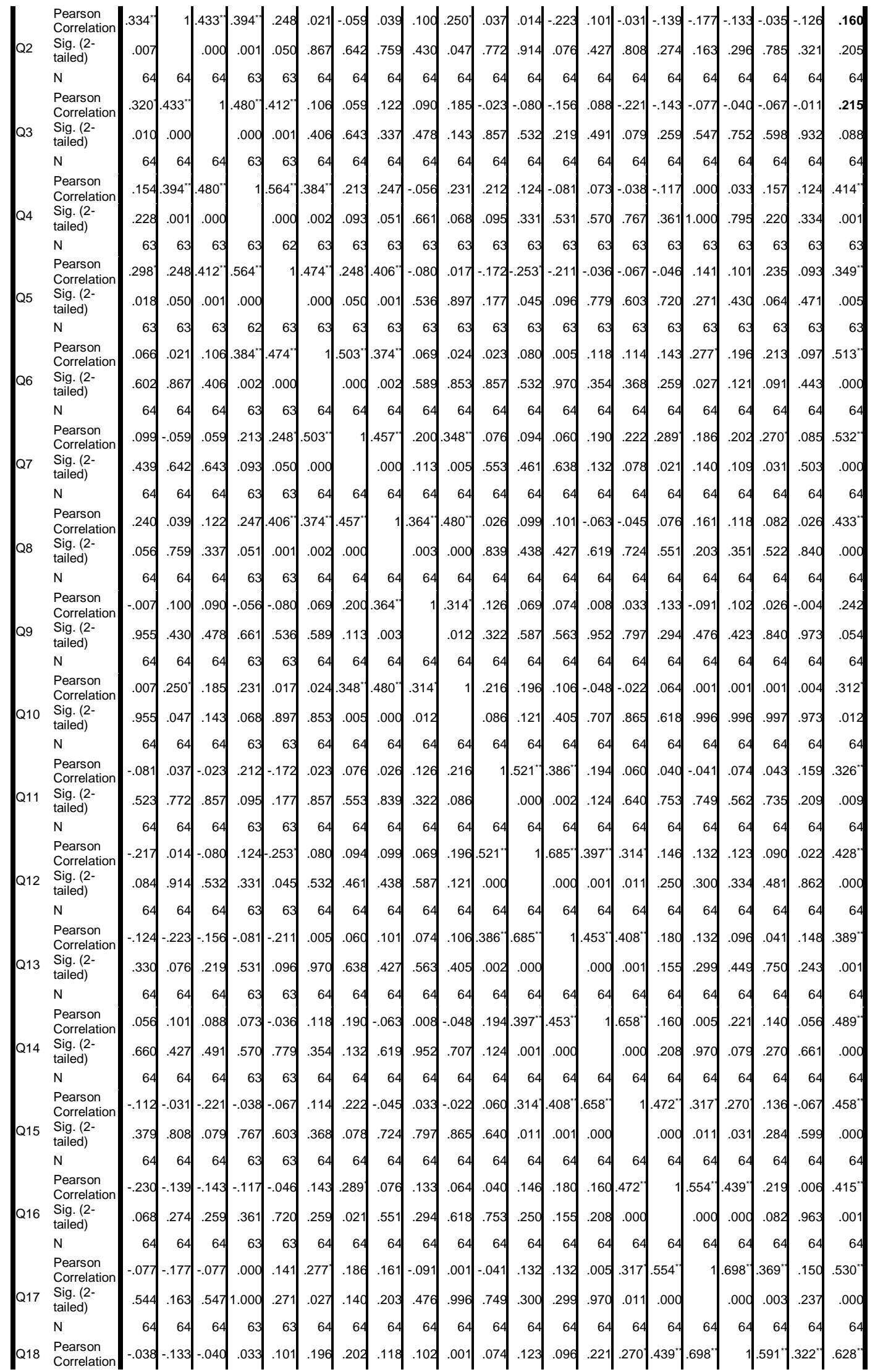




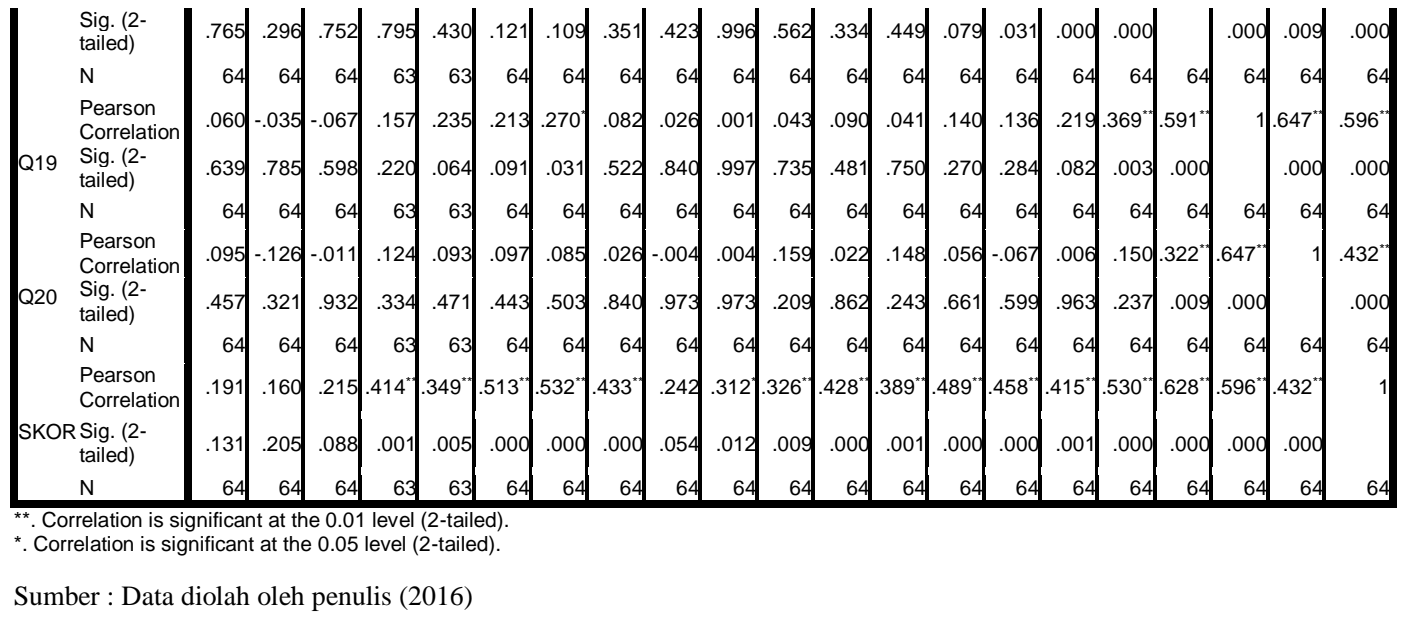

Dari table 4.4 soal nomor 1 sampai dengan nomor 20 valid karena karena $r_{\text {hitung }}$ lebih besar dari $r_{\text {tabel }}\left(r_{\text {hitung }}>r_{\text {tabel }}\right)$ yakni 0,15979. Jadi analisis data kuesioner yang dipakai adalah kuesioner yang valid sebanyak 20 soal. (Sugiyono, 2012:126).

b. Variabel Keterampilan Membuat Bahan Ajar (Y)

Tabel 5.5 Hasil Perhitungan r pada Variabel Keterampilan (Y)

\begin{tabular}{|c|c|c|c|c|c|c|c|c|c|c|c|c|c|c|c|c|c|}
\hline \multicolumn{18}{|c|}{ Correlations } \\
\hline & & Q1 & Q2 & Q3 & Q4 & Q5 & Q6 & Q7 & Q8 & Q9 & Q10 & Q11 & $\begin{array}{c}\mathrm{Q} 1 \\
2\end{array}$ & Q13 & $\begin{array}{c}\text { Q1 } \\
4\end{array}$ & Q15 & $\begin{array}{c}\text { SKO } \\
\text { R }\end{array}$ \\
\hline & $\begin{array}{l}\text { Pearson } \\
\text { Correlatio } \\
n\end{array}$ & 1 & .173 & $.249^{*}$ & .130 & .176 & -.033 & -.066 & .005 & .051 & -.169 & .105 & .22 & -.101 & $\begin{array}{r}.20 \\
3\end{array}$ & .062 & .239 \\
\hline Q1 & $\begin{array}{l}\text { Sig. (2- } \\
\text { tailed) }\end{array}$ & & .171 & .047 & .305 & .163 & .797 & .607 & .969 & .690 & .181 & .411 & $\begin{array}{r}.07 \\
6\end{array}$ & .428 & $\begin{array}{r}.10 \\
7\end{array}$ & .626 & .057 \\
\hline & $\mathrm{N}$ & 64 & 64 & 64 & 64 & 64 & 63 & 64 & 64 & 64 & 64 & 64 & 64 & 64 & 64 & 64 & 64 \\
\hline & $\begin{array}{l}\text { Pearson } \\
\text { Correlatio } \\
\mathrm{n}\end{array}$ & .173 & 1 & $.575^{*}$ & $.374^{*}$ & .176 & -.150 & -.028 & .144 & $.262^{*}$ & -.037 & .233 & $\begin{array}{r}- \\
.12 \\
5\end{array}$ & .175 & $\begin{array}{r}.02 \\
8\end{array}$ & .062 & $.472 *$ \\
\hline Q2 & $\begin{array}{l}\text { Sig. (2- } \\
\text { tailed) }\end{array}$ & .171 & & .000 & .002 & .163 & .241 & .828 & .255 & .036 & .771 & .064 & $\begin{array}{r}.32 \\
6\end{array}$ & .166 & $\begin{array}{r}.82 \\
7\end{array}$ & .626 & .000 \\
\hline & $\mathrm{N}$ & 64 & 64 & 64 & 64 & 64 & 63 & 64 & 64 & 64 & 64 & 64 & 64 & 64 & 64 & 64 & 64 \\
\hline & $\begin{array}{l}\text { Pearson } \\
\text { Correlatio } \\
\mathrm{n}\end{array}$ & .249 & $.575^{\star}$ & 1 & $.440^{\circ}$ & $.296^{*}$ & -.083 & .005 & .066 & .102 & -.045 & .188 & $\begin{array}{r}-10 \\
5\end{array}$ & .208 & $\begin{array}{r}.06 \\
4\end{array}$ & .232 & $.509^{* *}$ \\
\hline Q3 & $\begin{array}{l}\text { Sig. (2- } \\
\text { tailed) }\end{array}$ & .047 & .000 & & .000 & .017 & .516 & .969 & .605 & .423 & .724 & .136 & $\begin{array}{r}.40 \\
8\end{array}$ & .099 & $\begin{array}{r}.61 \\
7\end{array}$ & .065 & .000 \\
\hline & & 64 & 64 & 64 & 64 & 64 & 63 & 64 & 64 & 64 & 64 & 64 & 64 & 64 & 64 & 64 & 64 \\
\hline & $\begin{array}{l}\text { Pearson } \\
\text { Correlatio } \\
\mathrm{n}\end{array}$ & .130 & .374 & $.440^{*}$ & 1 & $.353^{*}$ & -.079 & -.087 & .038 & -.104 & -.125 & .173 & $\begin{array}{r}.07 \\
2\end{array}$ & .193 & $\begin{array}{r}.12 \\
6\end{array}$ & $.271^{*}$ & $.480^{\circ}$ \\
\hline Q4 & $\begin{array}{l}\text { Sig. (2- } \\
\text { tailed) }\end{array}$ & .305 & .002 & .000 & & .004 & .536 & .497 & .765 & .413 & .326 & .172 & $\begin{array}{r}.57 \\
0\end{array}$ & .127 & $\begin{array}{r}.32 \\
2\end{array}$ & .030 & .000 \\
\hline & $\mathrm{N}$ & 64 & 64 & 64 & 64 & 64 & 63 & 64 & 64 & 64 & 64 & 64 & 64 & 64 & 64 & 64 & 64 \\
\hline & $\begin{array}{l}\text { Pearson } \\
\text { Correlatio } \\
\mathrm{n}\end{array}$ & .176 & .176 & $.296^{*}$ & $.353^{*}$ & 1 & .078 & .090 & -.029 & -.051 & -.128 & .175 & $\begin{array}{r}.07 \\
2\end{array}$ & .155 & $\begin{array}{r}.09 \\
5\end{array}$ & .042 & $.370^{* *}$ \\
\hline Q5 & $\begin{array}{l}\text { Sig. (2- } \\
\text { tailed) }\end{array}$ & .163 & .163 & .017 & .004 & & .546 & .479 & .819 & .689 & .313 & .166 & $\begin{array}{r}.57 \\
1\end{array}$ & .222 & $\begin{array}{r}.45 \\
5\end{array}$ & .740 & .003 \\
\hline & $\mathrm{N}$ & 64 & 64 & 64 & 64 & 64 & 63 & 64 & 64 & 64 & 64 & 64 & 64 & 64 & 64 & 64 & 64 \\
\hline & $\begin{array}{l}\text { Pearson } \\
\text { Correlatio } \\
n\end{array}$ & .033 & -.150 & -.083 & -.079 & .078 & 1 & $.419^{*}$ & $.377^{\star}$ & .194 & .183 & -.048 & $\begin{array}{r}. \\
.03 \\
3\end{array}$ & .163 & $\begin{array}{r}- \\
.01 \\
8\end{array}$ & .196 & $.375^{* *}$ \\
\hline Q6 & $\begin{array}{l}\text { Sig. (2- } \\
\text { tailed) }\end{array}$ & .797 & .241 & .516 & .536 & .546 & & .001 & .002 & .129 & .152 & .707 & $\begin{array}{r}.79 \\
5\end{array}$ & .202 & $\begin{array}{r}.89 \\
1\end{array}$ & .123 & .002 \\
\hline & & 63 & 63 & 63 & 63 & 63 & 63 & 63 & 63 & 63 & 63 & 63 & 63 & 63 & 63 & 63 & 63 \\
\hline & $\begin{array}{l}\text { Pearson } \\
\text { Correlatio } \\
n\end{array}$ & .066 & -.028 & .005 & -.087 & .090 & $.419^{\circ}$ & 1 & $.503^{\star}$ & $.534^{*}$ & $.357^{*}$ & .133 & $\begin{array}{r}.01 \\
6\end{array}$ & -.010 & $\begin{array}{r}- \\
.15 \\
8\end{array}$ & .114 & $.453^{* *}$ \\
\hline Q7 & $\begin{array}{l}\text { Sig. (2- } \\
\text { tailed) }\end{array}$ & .607 & .828 & .969 & .497 & .479 & .001 & & .000 & .000 & .004 & .296 & $\begin{array}{r}.90 \\
3\end{array}$ & .939 & $\begin{array}{r}.21 \\
4\end{array}$ & .372 & .000 \\
\hline & & 64 & 64 & 64 & 64 & 64 & 63 & 64 & 64 & 64 & 64 & 64 & 64 & 64 & 64 & 64 & 64 \\
\hline Q8 & $\begin{array}{l}\text { Pearson } \\
\text { Correlatio } \\
\mathrm{n}\end{array}$ & .005 & .144 & .066 & .038 & -.029 & $.377^{\circ}$ & $.503^{*}$ & 1 & $.548^{*}$ & .198 & 200 & $\begin{array}{r}.05 \\
7\end{array}$ & -.185 & $\begin{array}{r}- \\
.0 \\
1\end{array}$ & -.044 & $.447^{* *}$ \\
\hline
\end{tabular}




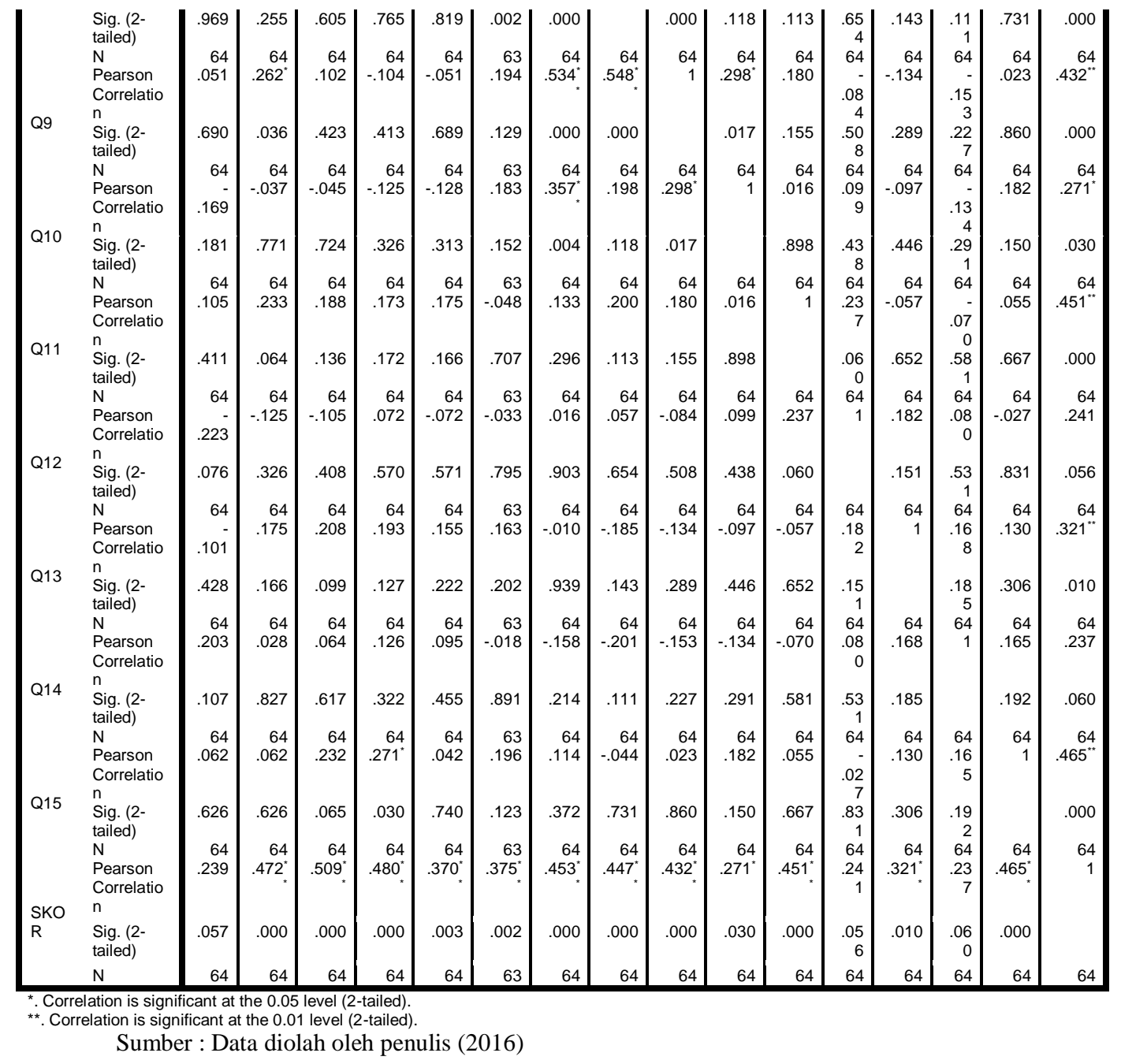

Dari tabel 4.5 soal nomor 1 sampai dengan nomor 15 valid karena karena $r_{\text {hitung }}$ lebih besar dari $r_{\text {tabel }}\left(r_{\text {hitung }}>r_{\text {tabel }}\right)$ yakni 0,15979. Jadi analisis data kuesioner yang dipakai adalah kuesioner yang valid sebanyak 15soal. (Sugiyono, 2012:126).

\section{Uji Reliabilitas}

Uji reliabilitas dilakukan kepada 64 orang responden dan perhitungannya menggunakan rumus Alpha Cronbach. Kuesioner yang akan diuji sebanyak 20 soal untuk variable $X$ dan 15 soal untuk variabel Y. Kriteria pengujiannya adalah apabila nilai $r_{\text {hitung }}>\mathrm{r}$ tabel, maka instrument dinyatakan reliable. Dan sebaliknya apabila $\mathrm{r}_{\text {hitung }}<\mathrm{r}$ tabel, maka instrument dinyatakan tidak reliable. Jika nilai alpha $>0.7$ artinya reliabilitas mencukupi (sufficient reliability) sementara jika alpha $>0.80$ ini 
mensugestikan seluruh item reliabel dan seluruh tes secara konsisten memiliki reliabilitas yang kuat. Atau, ada pula yang memaknakannya sebagai berikut:

Jika alpha $>0.90$ maka reliabilitas sempurna. Jika alpha antara $0.70-0.90$ maka reliabilitas tinggi. Jika alpha $0.50-0.70$ maka reliabilitas moderat. Jika alpha $<0.50$ maka reliabilitas rendah. Jika alpha rendah, kemungkinan satu atau beberapa item tidak reliable (http://qmc.binus.ac.id/2014/11/01/u-j-i-v-a-1-i-d-i-t-a-s-d-a-n-u-j-i-re-1-i-a-b-i-1-i-t-a-s/).

a. Variabel Motivasi Belajar (X)

Tabel 5.6

Hasil Perhitungan Uji Reliabilitas Pada Variabel Motivasi Belajar (X)

\begin{tabular}{|c|c|c|c|}
\hline \multicolumn{4}{|c|}{ Case Processing Summary } \\
\hline & & $\mathrm{N}$ & $\%$ \\
\hline \multirow{3}{*}{ Cases } & Valid & 62 & 96.9 \\
\hline & Excluded $^{a}$ & 2 & 3.1 \\
\hline & Total & 64 & 100.0 \\
\hline
\end{tabular}

a. Listwise deletion based on all variables in the procedure.

Reliability Statistics

\begin{tabular}{|l|l|}
\hline Cronbach's Alpha & $\mathrm{N}$ of Items \\
\hline
\end{tabular}

Item-Total Statistics

\begin{tabular}{|c|c|c|c|c|}
\hline & $\begin{array}{c}\text { Scale Mean if } \\
\text { Item Deleted }\end{array}$ & $\begin{array}{c}\text { Scale Variance if } \\
\text { Item Deleted }\end{array}$ & $\begin{array}{c}\text { Corrected Item- } \\
\text { Total Correlation }\end{array}$ & $\begin{array}{c}\text { Cronbach's Alpha } \\
\text { if Item Deleted }\end{array}$ \\
\hline Q1 & 149.69 & 131.954 & .133 & .712 \\
Q2 & 149.50 & 132.025 & .117 & .713 \\
Q3 & 149.52 & 131.205 & .172 & .711 \\
Q4 & 149.60 & 128.474 & .406 & .703 \\
Q5 & 149.55 & 129.104 & .311 & .706 \\
Q6 & 149.65 & 127.052 & .484 & .700 \\
Q7 & 149.69 & 125.790 & .524 & .697 \\
Q8 & 149.74 & 128.162 & .414 & .703 \\
Q9 & 149.73 & 131.284 & .205 & .710 \\
Q10 & 149.71 & 130.341 & .295 & .708 \\
Q11 & 150.08 & 129.092 & .287 & .706 \\
Q12 & 149.98 & 127.393 & .389 & .702 \\
Q13 & 149.97 & 127.868 & .346 & .703 \\
Q14 & 149.89 & 125.741 & .432 & .700 \\
Q15 & 149.94 & 126.586 & .402 & .701 \\
Q16 & 149.82 & 127.034 & .394 & .696 \\
Q17 & 149.69 & 124.872 & .476 & .689 \\
Q18 & 149.69 & 122.282 & .580 & .689 \\
Q19 & 149.71 & 122.013 & .548 & .700 \\
Q20 & 149.68 & 125.665 & .360 & .755 \\
SK0R & 76.79 & 33.480 & 1.000 & \\
\hline
\end{tabular}

Sumber : Data diolah oleh penulis (2016)

Menurut Sugiyono (2012:184), suatu instrument dinyatakan reliabel apabila $\alpha>0,60$. Dari perhitungan diatas menunjukkan bahwa reliabilitas termasuk dalam kategori (0,800-1,000), maka instrument memiliki 
reliabilitas yang sangat tinggi.

b. Variabel Keterampilan Membuat Bahan Ajar (Y)

Tabel 5.7

Hasil Perhitungan Uji Reliabilitas Pada Variable Keterampilan Membuat Bahan Ajar (Y)

Case Processing Summary

\begin{tabular}{|ll|r|r|}
\hline & & \multicolumn{1}{|c|}{$\%$} \\
\hline \multirow{3}{*}{ Cases } & Valid & 63 & 98.4 \\
& Excluded $^{\mathrm{a}}$ & 1 & 1.6 \\
& Total & 64 & 100.0 \\
\hline
\end{tabular}

a. Listwise deletion based on all variables in the procedure.

Reliability Statistics

\begin{tabular}{|l|l|l|}
\hline Cronbach's Alpha & Cronbach's Alpha Based on Standardized Items & $\mathrm{N}$ of Items \\
\hline
\end{tabular}

\begin{tabular}{r|r|r|}
\hline 675 & .693 & 16 \\
\hline
\end{tabular}

\begin{tabular}{|l|r|r|r|}
\multicolumn{5}{c|}{ Item Statistics } \\
\hline & Mean & Std. Deviation & $\mathrm{N}$ \\
\hline Q1 & 4.02 & .609 & 63 \\
Q2 & 4.03 & .595 & 63 \\
Q3 & 3.89 & .650 & 63 \\
Q4 & 3.81 & .644 & 63 \\
Q5 & 3.90 & .615 & 63 \\
Q6 & 3.83 & .661 & 63 \\
Q7 & 3.73 & .700 & 63 \\
Q8 & 3.87 & .751 & 63 \\
Q9 & 3.81 & .618 & 63 \\
Q10 & 3.86 & .592 & 63 \\
Q11 & 3.76 & .817 & 63 \\
Q12 & 3.81 & .800 & 63 \\
Q13 & 3.92 & .768 & 63 \\
Q14 & 4.03 & .897 & 63 \\
Q15 & 3.92 & .885 & 63 \\
SKOR & 58.19 & 4.044 & 63 \\
\hline
\end{tabular}

Item-Total Statistics

\begin{tabular}{|l|r|r|r|r|r|}
\hline & $\begin{array}{c}\text { Scale Mean if } \\
\text { Item Deleted }\end{array}$ & $\begin{array}{c}\text { Scale Variance if } \\
\text { Item Deleted }\end{array}$ & $\begin{array}{c}\text { Corrected Item- } \\
\text { Total Correlation }\end{array}$ & $\begin{array}{c}\text { Squared Multiple } \\
\text { Correlation }\end{array}$ & $\begin{array}{c}\text { Cronbach's Alpha if } \\
\text { Item Deleted }\end{array}$ \\
\hline Q1 & 112.37 & 63.332 & .175 & &. \\
Q2 & 112.35 & 61.521 & .378 &. & .672 \\
Q3 & 112.49 & 60.189 & .475 &. & .660 \\
Q4 & 112.57 & 61.023 & .394 &. & .652 \\
Q5 & 112.48 & 61.899 & .323 &. & .657 \\
Q6 & 112.56 & 61.832 & .301 &. & .662 \\
Q7 & 112.65 & 60.392 & .415 &. & .663 \\
Q8 & 112.51 & 60.770 & .347 &. & .654 \\
Q9 & 112.57 & 61.700 & .341 &. & .658 \\
Q10 & 112.52 & 63.512 & .163 &. & .661 \\
Q11 & 112.62 & 60.272 & .351 &. & .672 \\
Q12 & 112.57 & 63.249 & .119 &. & .657 \\
Q13 & 112.46 & 61.801 & .249 &. & .676 \\
Q14 & 112.35 & 62.037 & .181 & .367 \\
Q15 & 112.46 & 59.736 & .357 &. & .671 \\
SKOR & 58.19 & 16.350 & 1.000 &. & .655 \\
\hline
\end{tabular}

Scale Statistics

\begin{tabular}{|l|l|l|l|}
\hline Mean & Variance & Std. Deviation & $\mathrm{N}$ of Items \\
\hline
\end{tabular}

\begin{tabular}{r|r|r|r|}
\hline 116.38 & 65.401 & 8.087 & 16 \\
\hline
\end{tabular}


ANOVA

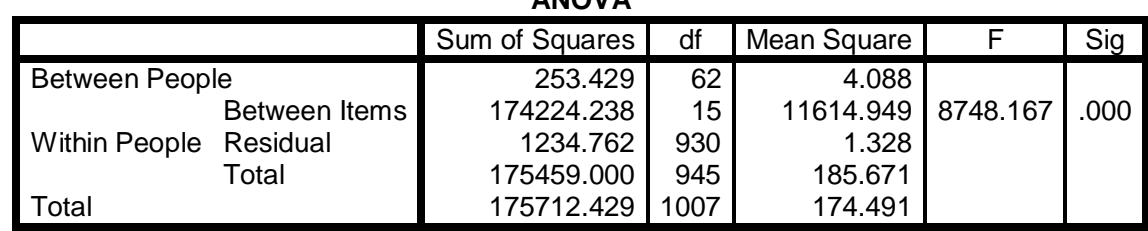

Grand Mean $=7.27$

Sumber : Data diolah oleh penulis (2016)

Menurut Sugiyono (2012:184), suatu instrument dinyatakan reliabel apabila $\alpha>0,60$. Dari perhitungan diatas menunjukkan bahwa reliabilitas termasuk dalam kategori (0,800-1,000), maka instrument memiliki reliabilitas yang tinggi.

\section{Data Skor Variabel Motivasi Belajar dan Kemampuan Membuat Bahan Ajar}

Data penelitian ini menyangkut dua variable yaitu terdiri atas variabel bebas (X) dan variable terikat (Y). Variable bebas adalah Motivasi Belajar, sedangkan variabel terikat adalah Keterampilan. Jumlah subyek penelitian yang datanya telah memenuhi syarat untuk dianalisa ada 64 responden yang merupakan guru mata pelajaran di SMP Negeri 139 Jakarta. Cara pengumpulan data untuk variabel X dan Y dilakukan dengan membagikan kuesioner kepada 64 responden yang berisikan dua puluh pernyataan untuk variabel Motivasi Belajar (X), dan lima belas pernyataan untuk variabel Keterampilan (Y) yang terdiri dari lima pilihan jawaban.

Tabel 5.8 Data skor variable Motivasi Belajar (variabel X) dan variable

Keterampilan (Y)
\begin{tabular}{|c|c|c|}
\hline Responden & $X$ & $Y$ \\
\hline 1 & 86 & 58 \\
\hline 2 & 76 & 61 \\
\hline 3 & 81 & 58 \\
\hline 4 & 77 & 65 \\
\hline 5 & 82 & 58 \\
\hline 6 & 70 & 63 \\
\hline 7 & 78 & 60 \\
\hline 8 & 74 & 59 \\
\hline 9 & 69 & 56 \\
\hline 10 & 81 & 56 \\
\hline 11 & 80 & 54 \\
\hline 12 & 77 & 64 \\
\hline 13 & 86 & 64 \\
\hline 14 & 84 & 65 \\
\hline 15 & 82 & 54 \\
\hline 16 & 86 & 54 \\
\hline 17 & 78 & 54 \\
\hline 18 & 85 & 62 \\
\hline 19 & 78 & 61 \\
\hline 20 & 65 & 60 \\
\hline 21 & 75 & 58 \\
\hline 22 & 88 & 64 \\
\hline 23 & 77 & 59 \\
\hline & & \\
\hline
\end{tabular}


Relasi : Jurnal Ekonomi, Vol. 15, No. 2, July 2019, hlm. 196-218

\begin{tabular}{|c|c|c|}
\hline 24 & 66 & 56 \\
\hline 25 & 69 & 63 \\
\hline 26 & 80 & 60 \\
\hline 27 & 73 & 59 \\
\hline 28 & 77 & 69 \\
\hline 29 & 73 & 62 \\
\hline 30 & 76 & 61 \\
\hline 31 & 81 & 53 \\
\hline 32 & 82 & 53 \\
\hline 33 & 79 & 64 \\
\hline 34 & 74 & 63 \\
\hline 35 & 69 & 61 \\
\hline 36 & 64 & 59 \\
\hline 37 & 72 & 55 \\
\hline 38 & 69 & 57 \\
\hline 39 & 70 & 64 \\
\hline 40 & 79 & 57 \\
\hline 41 & 72 & 61 \\
\hline 42 & 80 & 61 \\
\hline 43 & 79 & 55 \\
\hline 44 & 72 & 56 \\
\hline 45 & 76 & 58 \\
\hline 46 & 87 & 57 \\
\hline 47 & 78 & 55 \\
\hline 48 & 85 & 56 \\
\hline 49 & 70 & 54 \\
\hline 50 & 81 & 56 \\
\hline 51 & 84 & 57 \\
\hline 52 & 73 & 60 \\
\hline 53 & 82 & 55 \\
\hline 54 & 74 & 57 \\
\hline 55 & 73 & 55 \\
\hline 56 & 69 & 62 \\
\hline 57 & 72 & 53 \\
\hline 58 & 71 & 52 \\
\hline 59 & 78 & 51 \\
\hline 60 & 77 & 49 \\
\hline 61 & 80 & 55 \\
\hline 62 & 79 & 52 \\
\hline 63 & 73 & 52 \\
\hline 64 & 77 & 53 \\
\hline
\end{tabular}

Sumber : Data diolah oleh penulis (2016)

\section{Analisis Data}

Berdasarkan data yang diperoleh maka Motivasi Belajar Guru terhadap Keterampilan Membuat Bahan Ajar Berbasis Informasi dan Teknologi di SMP Negeri 139 Jakarta dapat dianalisa sebagai berikut.

Variables Entered/Removed ${ }^{a}$

\begin{tabular}{|l|l|l|l|}
\hline Model & Variables Entered & Variables Removed & Method \\
\hline 1 & Motivasi $^{\mathrm{b}}$ & & Enter \\
\hline
\end{tabular}

b. All requested variables entered.

Model Summary 


\begin{tabular}{l|c|r|r|r|}
\hline Model & $\mathrm{R}$ & $\mathrm{R}$ Square & Adjusted R Square & Std. Error of the Estimate \\
\hline 1 & $.043^{\mathrm{a}}$ & .002 & -.014 & 4.202 \\
\hline
\end{tabular}

ANOVA $^{\mathrm{a}}$

\begin{tabular}{|l|r|r|r|r|l|}
\hline Model & Sum of Squares & df & Mean Square & F & Sig. \\
\hline Regression & 2.001 & 1 & 2.001 & .113 & $.738^{\mathrm{b}}$ \\
1 Residual & 1094.858 & 62 & 17.659 & & \\
$\quad$ Total & 1096.859 & 63 & & & \\
\hline
\end{tabular}

a. Dependent Variable: Keterampilan

b. Predictors: (Constant), Motivasi

Coefficients $^{a}$

\begin{tabular}{|c|c|c|c|c|c|}
\hline \multirow[t]{2}{*}{ Model } & \multicolumn{2}{|c|}{ Unstandardized Coefficients } & \multirow{2}{*}{\begin{tabular}{|c} 
Standardized Coefficients \\
Beta
\end{tabular}} & \multirow[t]{2}{*}{$\mathrm{t}$} & \multirow[t]{2}{*}{ Sig. } \\
\hline & B & Std. Error & & & \\
\hline $1 \begin{array}{l}\text { (Constant) } \\
\text { Motivasi }\end{array}$ & $\begin{array}{r}60.440 \\
-.031\end{array}$ & $\begin{array}{r}7.128 \\
.093\end{array}$ & -.043 & $\begin{array}{l}8.479 \\
-.337\end{array}$ & $\begin{array}{l}.000 \\
.738\end{array}$ \\
\hline
\end{tabular}

a. Dependent Variable: Keterampilan

Dari hasil perhitungan analisis regresi diperoleh persamaan yaitu $\widehat{Y}=$ $60,440-0,31 X$, artinya setiap perubahan nilai variabel $X$, maka akan diikuti dengan perubahan nilai Y. dari hasil penghitungan regresi juga didapatkan bahwa terdapat kecenderungan menurun sebesar $31 \%$ dari setiap perubahan $1 \%$ dari variabel X.

\section{Analisis Koefisien Korelasi}

Untuk menguji hubungan antara variable $\mathrm{X}$ (Motivasi Belajar) dengan variable $\mathrm{Y}$ (Keterampilan Membuat Bahan Ajar), maka peneliti menggunakan uji koefisiensi korelasi. Dengan menggunakan hsil penghitungan SPSS maka diperoleh hasil sebagai berikut:

\begin{tabular}{|rl|r|r|}
\hline \multicolumn{3}{|c|}{ Correlations } \\
\hline \multirow{4}{*}{ Motivasi } & Motivasi & Keterampilan \\
& Pearson Correlation & 1 & -.043 \\
& Sig. (2-tailed) & & .738 \\
& $\mathrm{~N}$ & 64 & 64 \\
\multirow{4}{*}{ Keterampilan } & Pearson Correlation & -.043 & 1 \\
& Sig. (2-tailed) & .738 & \\
& $\mathrm{~N}$ & 64 & 64 \\
\hline
\end{tabular}

Dari hasil perhitungan dapat diketahui bahwa terdapat pengaruh positif dimana nilai korelasi antara variabel X (Motivasi Belajar) dengan variabel Y (Keterampilan Membuat Bahan Ajar) sebesar -0,43. Hal ini dapat dijelaskan bahwa kekuatan hubungan antara variabel $\mathrm{X}$ terhadap $\mathrm{Y}$ memiliki kecenderungan yang negatif 
dengan nilai kekuatan sebesar 0,043 yang diterjemahkan sebagai SANGAT RENDAH. Interpretasi dari hasil koefisien korelasi tersebut dapat dijelaskan pada tabel sebagai berikut:

Tabel 5.10 Tabel Interpretasi Koefisien Korelasi

\begin{tabular}{|c|c|}
\hline Besarnya Koefisien & Klasifikasi \\
\hline $0,000-0,199$ & Sangat Rendah \\
\hline $0,200-0,399$ & Rendah \\
\hline $0,400-0,599$ & Sedang \\
\hline $0,600-0,799$ & Kuat \\
\hline $0,800-1,000$ & Sangat Kuat \\
\hline
\end{tabular}

Sumber: Sugiyono, (2012:250)

Dalam penelitian ini, Peneliti juga menggunakan uji Determinasi yang dimaksudkan untuk dapat mengetahui seberapa besar prosentase perubahan variabel (X) dapat mempengaruhi perubahan variabel (Y), maka digunakan perhitungan koefisien determinasi dari nilai $r$ dengan dengan hasil sebagai berikut:

\section{Model Summary}

\begin{tabular}{|l|r|r|r|c|}
\hline Model & $\mathrm{R}$ & $\mathrm{R}$ Square & $\begin{array}{c}\text { Adjusted R } \\
\text { Square }\end{array}$ & $\begin{array}{c}\text { Std. Error of the } \\
\text { Estimate }\end{array}$ \\
\hline 1 & $.043^{\mathrm{a}}$ & $\mathbf{. 0 0 2}$ & -.014 & 4.202 \\
\hline
\end{tabular}

a. Predictors: (Constant), Motivasi

Berdasarkan data di atas, maka didapatkan hasil penghitungan koefisen determinasi adalah sebesar 0,002 atau $0,2 \%$. Interpretasi dari koefisen determinasi tersebut adalah SANGAT RENDAH. Hal ini dapat diterjemahkan bahwa ternyata Motivasi belajar guru di SMP Negeri 139 Jakarta sangat lemah sehingga tidak mampu berkontribusi terhadap perubahan atas kemampuan guru-guru tersebut dalam membuat bahan ajar di sekolah tersebut. Berdasarkan data tersebut, dapat di terjemahkan pula bahwa sebesar 99,8\% merupakan faktor lain yang mampu memberikan kontribusi terhadap kemampuan guru untuk terampil dalam membuat bahan ajar.

\section{Uji Hipotesis}

Uji hipotesis dimaksudkan untuk mendapatkan kesimpulan hasil penelitian dengan menggunakan teknik korelasional dengan menggunakan rumus sebagai berikut, (Sugiyono, 2012:184). Dalam penelitian ini, peneliti menggunakan uji t (t-test) 
untuk menguji keabsahan hipotesis.

\section{a. Kriteria Pengujian}

Jika $t_{\text {hitung }}>t_{\text {tabel }}$ maka Ha diterima, Ho ditolak, Jika $t_{\text {hitung }}<t_{\text {tabel }}$ maka Ha ditolak, Ho diterima

\begin{tabular}{|c|c|c|c|c|c|}
\hline \multicolumn{6}{|c|}{ Coefficients $^{\mathrm{a}}$} \\
\hline \multirow[t]{2}{*}{ Model } & \multicolumn{2}{|c|}{ Unstandardized Coefficients } & \multirow{2}{*}{$\frac{\text { Standardized Coefficien }}{\text { Beta }}$} & \multirow[t]{2}{*}{$\mathrm{t}$} & \multirow[t]{2}{*}{ Sig. } \\
\hline & B & Std. Error & & & \\
\hline (Constant) & 60.440 & 7.128 & & 8.479 & .000 \\
\hline Motivasi & -.031 & .093 & -.04 & -.337 & .738 \\
\hline
\end{tabular}

Berdasarkan kriteria pengujian di atas, dengan mengambil nilai $t_{\text {tabel }}$ pada $\alpha=20 \%$ sebesar 1.29492, diperoleh hasil $t_{\text {hitung }}$ sebesar 8,479. Kondisi dapat diterjemahkan bahwa nilai $\mathrm{t}_{\text {hitung }}$ lebih besar daripada nilai $\mathrm{t}_{\text {tabel }}$. Sehingga berdasarkan interpretasi hipotesis yang telah dilakukan maka dapat disimpulkan bahwa Ha diterima. Yaitu Terdapat Pengaruh antara Motivasi Belajar Guru terhadap Keterampilan Membuat Bahan Ajar.

Kondisi dapat diterjemahkan bahwa nilai $\mathrm{t}_{\text {hitung }}$ lebih besar daripada nilai $\mathrm{t}_{\text {tabel }}$. Sehingga berdasarkan interpretasi hipotesis yang telah dilakukan maka dapat disimpulkan bahwa Ha diterima. Yaitu Terdapat Pengaruh antara Motivasi Belajar Guru terhadap Keterampilan Membuat Bahan Ajar.

Berdasarkan hasil penelitian yang telah dilakukan, maka dapat diinterprestasikan bahwa terdapat pengaruh antara motivasi belajar guru dengan kemampuan guru dalam membuat bahan ajar di SMP Negeri 139 Jakarta yang dibuktikan dari hasil perhitungan koefisien korelasi yang diperoleh sebesar 0,043 atau 4,3\%. Hasil tersebut dapat diinterpretasikan bahwa Motivasi Belajar memiliki keeratan hubungan yang sangat rendah terhadap Kemampuan Membuat Bahan Ajar guru di SMP Negeri 139 Jakarta. Hal ini dikarenakan $r=0,043$ terletak antara 0,000 - 0,199, yang berarti mempunyai korelasi yang sangat rendah sebagaimana yang tercantum pada tabel interpretasi dari nilai koefisien korelasi. Kondisi tersebut dapat dijelaskan bahwa sebagian guru memiliki kesadaran yang rendah terhadap pentingnya penggunaan teknologi informasi (komputer) sebagai sarana pendukung 
dalam proses belajar dan mengajar di kelas masing-masing. Hal ini diperkuat lagi bahwa sebagian guru merasa tidak perlu dalam menggunakan sarana berbasis teknologi dan informasi tersebut dikarenakan merasa bahwa faktor usia menjadi kendala untuk terampil menggunakan computer; Dari perhitungan koefisien determinasi, besarnya Motivasi Belajar cukup signifikan mempengaruhi Keterampilan didapat sebesar 0,2\%, hal ini menunjukkan bahwa Motivasi Belajar sangat lemah dalam memberikan pengaruh terhadap kemampuan guru dalam membuat bahan ajar. Berdasarkan data tersebut pula, tentunya kondisi tersebut dipengaruhi oleh faktor lain sebesar 99,8\%; Dalam uji hipotesis, nilai $t_{\text {hitung }}$ ternyata lebih besar dibandingkan dengan nilai $t_{\text {tabel }}$ yaitu sebesar 8,479 $\geq 1.29492$, berarti Ha diterima dan Ho ditolak, artinya terdapat korelasi yang signifikan antara variabel $\mathrm{X}$ dan variabel Y.; Dan dari hasil perhitungan analisis regresi diperoleh persamaan yaitu $\hat{Y}=60,440-0,31 X$, artinya setiap perubahan $1 \%$ dari nilai variabel $\mathrm{X}$, maka akan diikuti dengan perubahan nilai $\mathrm{Y}$ sebesar $31 \%$ dengan kecenderungan yang menurun (negatif). Jadi setiap kenaikan variable $\mathrm{X}$, maka akan menurunkan variable $\mathrm{Y}$.

\section{Kesimpulan}

Berdasarkan hasil penelitian yang telah dilakukan pada guru-guru mata pelajaran di SMP Negeri 139 Jakarta dalam upaya mengetahui dan mengukur motivasi belajar mereka yang berdampak terhadap keterampilan guru tersebut dalam membuat bahan ajar, maka dapat disimpulkan beberapa hal sebagai berikut:

1). SMP Negeri 139 Jakarta merupakan salah satu sekolah unggulan di wilayah timur DKI Jakarta yang sedang melakukan peningkatan kualitas pendidikan dan pembelajaran di kelas melalui proses pemberdayaan seluruh tenaga pengajar yang merupakan salah satu kriteria yang telah ditetapkan oleh pemerintah terhadap sekolah tersebut ada dengan memberikan program pelatihan komputer berbasis informasi dan teknologi. Harapan dari output yang diunculkan dari pelatihan tersebut adalah guru matapelajaran lebih terampil dalam menggunakan program berbasis informasi dan teknologi sebagai sarana pendukung dalam proses pembelajarannya di kelas kepada siswa. 
2). Pada penelitian yang telah dilakukan, pada kenyataanya terdapat kondisi di mana sebagian besar guru mengalami kesulitan dalam mengoperasikan komputer sehingga dengan kondisi tersebut ternyata menjadi salah satu faktor utama yang mempengaruhi keterampilan guru tersebut dalam membuat bahan ajar

3). Hasil penelitian menunjukkan bahwa terdapat hubungan kausalitas dan itensitas pengaruh yang sangat lemah antara motivasi belajar guru itu sendiri terhadap keterampilan yang dihasilkan dari pelatihan tersebut. Walaupun di sisi lain, hipotesis membuktikan bahwa memang terdapat pengaruh antara motivasi belajar terhadap keterampilan guru di SMP Negeri 139 Jakarta dalam membuat bahan ajar.

4). Interpretasi dari hasil penelitian tersebut adalah ternyata motivasi belajar bukan merupakan faktor utama untuk membuat guru terampil dalam membuat bahan ajar itu sendiri. Hal ini terbukti dari hasil koefisien regresi yang menunjukkan kecenderungan negatif (penurunan) sebesar 31\% yang artinya dapat diterjemahkan bahwa berapapun besarnya peningkatan motivasi yang dilakukan, justru selalu memperkecil kemampuan dan keterampilan guru tersebut dalam membuat bahan ajar.

Ada faktor-faktor lain yang kemungkinan dapat membuat guru tersebut bisa terampil dalam membuat bahan ajar, seperti "paksaan" dari sekolah untuk selalu mengikuti program pelatihan, lingkungan kerja yang harus kondusif untuk mendorong guru tersebut harus menggunakan komputer, dan lain sebagainya.

Berdasarkan hasil penelitian dan simpulan telah tercantum di atas, maka dalam hal ini peneliti memberikan beberapa saran terkait dengan peningkatan keterampilan guru dalam membuat bahan ajar di SMP Negeri 139 Jakarta sebagai berikut:

1). Dibutuhkan dukungan dan peran serta seluruh stake holder yang terkait dengan keberadaan sekolah tersebut dalam meningkatkan kualitas pembelajaran dan pendidikan di SMP Negeri 139 Jakarta tersebut melalui support system dalam bentuk teknis riil dan kebijakan yang mampu memberikan kontribusi positif terhadap peningkatan kualitas pembelajaran tersebut terutama kepada tenaga pengajar itu sendiri 
2). Kepala sekolah, sebagai pihak yang berwenang dan bertanggung jawab penuh terhadap peningkatan kualitas pembelajaran di SMP Negeri 139 Jakarta dalam hal ini, harus pro aktif dalam menciptakan terobosan-terobosan baru dalam upaya meningkatkan motivasi guru itu sendiri untuk menggunakan sarana pembelajaran di kelas dengan berbasis teknolgi dan informasi,misalnya dengan melakukan kerjasama mutualisme dengan instansi terkait yang berwenang dalam menyelenggarakan pelatihan-pelatihan tersebut

3). Perlu diciptakan kesadaran yang berangkat dari individu guru tersebut bahwa memberikan ilmu dan pelajaran kepada siswa dengan kualitas yang baik melalui penggunaan sarana pembelajaran yang berbasis teknologi dan informasi adalah sangat penting, terutama di era teknologi saat ini. Tanpa menafikkan paradigm konvensional dari metode pembelajaran di kelas yang selama ini telah dilakukan oleh guru-guru tersebut, namun di sisi lain, gruu yang bersangkutan juga perlu melakukan proses pembelajaran yang berkualitas dan terbaik bagi siswa.

\section{DAFTAR PUSTAKA}

Bartol, Kathryn M., David C. Martin; 1998, Management; $3^{\text {rd }}$ Edition, The NcGraw-Hill, USA

Benowitz, Ellen A., 2001, Principles of Management, Hungry Minds, New York, USA

Handoko, T. Hani., 2012, Manajemen, Edisi 2, BPFE-Yogyakarta, Indonesia

Peraturan Pemerintah No. 74 Tahun 2008 tentang Guru

Mathis, Robert, L., dan John H, Jackson, 2010, Human Resources Management, $13^{\text {th }}$ edition, South Werstern, Cengage Learning, Mason, USA

Harrow, Anita J. (1972). A Taxonomy of the Psychomotor Domain. Longman Inc.

New York.

Magill, Ricahrd A. (1993) Motor Learning: Concepts and Applications (4th Ed.).

WMC. Brown. Dubuque. IA.

Schmidt, Richard A. (1991). Motor Learning and Performance: From Principle into Practice. 
Human Kinetics. Champaign, IL.

Singer, Robert N. (1980). Motor Learning and Human Performance: An Application to Motor

Skills and Movement Behaviors. Macmillan Pub. New York.

Sugiyono (2012), Metode Penelitian Kuantitatif, Kualitatif dan R\&D, Penerbit Alfabeta, Bandung, Indonesia,

Undang-Undang Republik Indonesia Nomor 14 Tahun 2005 Tentang Guru dan Dosen

http://www.businessdictionary.com/definition/skill.html http://file.upi.edu/Direktori/FPOK/JUR._PEND._OLAHRAGA/19630824198903 $\underline{\text { 1AGUS_MAHENDRA/Modul_Perkembangan_\%26_Belajar_Motorik_Agu }}$ s_Mahendra/Modul_7-_Keterampilan_dan_Taksonomi_Gerak.pdf

http://qmc.binus.ac.id/2014/11/01/u-j-i-v-a-1-i-d-i-t-a-s-d-a-n-u-j-i-r-e-l-i-a-b-i-1-i$\underline{\mathrm{t}-\mathrm{a}-\mathrm{s} /}$ 